\title{
Kierunki oddziaływania Krakowskiego Parku Technologicznego na rozwój województwa malopolskiego
}

\author{
The influence of Krakow Technology Park \\ on the development of Malopolska: an impact study
}

Streszczenie: Krakowski Park Technologiczny, mający status specjalnej strefy ekonomicznej, stanowi unikalne polączenie idei parku technologicznego oraz specjalnej strefy ekonomicznej. To pozwala mu w sposób zintegrowany oddzialywać na rozwój Malopolski w wymiarze:

- gospodarczym, obejmującym rozwój przedsiębiorczości, przyrost nowych miejsc pracy, bazy ekonomicznej regionu, dzięki szeroko rozumianym inwestycjom;

- środowiskowym, wiążącym się z poprawą i ochroną środowiska naturalnego, wdrażaniem nowoczesnych rozwiązań ekologicznych;

- infratechnicznym, obejmującym rozwój takich dziedzin, jak: drogi, transport, komputeryzację, internet;

- technicznym i technologicznym, poprzez współpracę przedsiębiorców z instytucjami badawczymi, krakowskimi uczelniami;

- społeczno-kulturowym, związanym z poziomem wykształcenia, efektami naśladownictwa, zmianami dochodów i konsumpcji itp.;

- przestrzennym, obejmującym zmiany w zagospodarowaniu Malopolski poprzez zagospodarowanie nowych terenów, lokalizację firm i instytucji.

Abstract: Cracow Technology Park with the status of a special economic zone is a unique combination of the idea of a technology park and a special economic zone. This allows it to have an intergal impact on the development of Malopolska region in a multidimensional way:

- Economic, including business development, creation of new work places, growth of the economic potential of the region due to broadly defined new investments, etc.

- Environmental, connected with environment protection and the implementation of modern environment friendly solutions,

- Infrastructural, including the development of areas such as: roads, transport, computerization, internet, etc.,

- Technical and technological, due to collaboration between entrepreneurs and research institutions such as Cracow universities, 
- Socio-cultural, associated with: the education level, the effects of imitation, changes in income and consumption patterns, etc.,

- Spatial, relating to changes in the management of Malopolska region by developing new sites, locating of new companies and institutions.

Slowa kluczowe: inwestycje; park technologiczny; pomoc publiczna; przedsiębiorczość; restrukturyzacja i modernizacja; rozwój lokalny; specjalna strefa ekonomiczna

Keywords: investments; region development; restructuring and modernization; special economic zone; state aid; technology park

\section{WsTĘP}

Specjalne Strefy Ekonomiczne (SSE) stanowią ważne narzędzie rozwoju gospodarczo-spolecznego na szczeblu lokalnym i krajowym. Ich utworzeniu w każdym z krajów towarzyszyły inne uwarunkowania i oczekiwania, lecz wspólnym mianownikiem stały się kierunki oddziaływania SSE na: restrukturyzację przemysłu, szeroko rozumianą przedsiębiorczość, wielkość i strukturę inwestycji poprzez przyciągnięcie krajowych i zagranicznych inwestorów, jakość infrastruktury, poziom i strukturę zatrudnienia, konkurencyjność obszaru strefy i szereg innych czynników rozwoju. Szczególnym rodzajem specjalnych stref ekonomicznych są parki technologiczne, których funkcjonowanie wynika ze wzrostu znaczenia wiedzy, technologii i informacji w rozwoju gospodarczym.

Celem niniejszego opracowania jest próba odpowiedzi na następujące pytania:

- na czym polega specyfika funkcjonujących SSE o statusie parków technologicznych?

- jaka jest geneza i uwarunkowania Krakowskiego Parku Technologicznego?

- jakie są główne kierunki, plaszczyzny i efekty oddzialywania Krakowskiego Parku Technologicznego na rozwój woj. małopolskiego?

Wydaje się, iż uzy skanie odpowiedzi na powyższe pytania jest szczególnie istotne, gdyż funkcjonowanie stref jest ograniczone w czasie i rodzi się wiele pytań o dalsze ich losy. System ulg, z których korzystają inwestorzy, zaklóca bowiem równoważną konkurencję pomiędzy podmiotami działającymi w strefie i poza nią. a tym samym zasady wspólnej polityki konkurencji Unii Europejskiej, w tym zasadę zakazu pomocy publicznej.

\section{POJECIE I ISTOTA SPECJALNYCH STREF EKONOMICZNYCH}

Uprzywilejowane strefy ekonomiczne, określane później mianem specjalnych stref ekonomicznych (SSE), mają długą historię, sięgającą XVI wieku.

W Polsce ich geneza łączy się z okresem transformacji gospodarczej (lata 90. XIX w.), obejmującej urynkowienie $\mathrm{i}$ restrukturyzację przemysłu oraz walkę $\mathrm{z}$ ich skutkami, m.in. bezrobociem, upadkiem firm itd. 
Zasady funkcjonowania oraz warunki tworzenia specjalnych stref ekonomicznych w Polsce oraz zarządzania nimi określone zostały w ustawie z 20 października 1994 r. o specjalnych strefach ekonomicznych, kilkakrotnie później nowelizowanej². Natomiast szczególowe kwestie dotyczące funkcjonowania poszczególnych SSE w Polsce określone zostały w rozporządzeniach Rady Ministrów dotyczących wszystkich SSE oraz w kilkudziesięciu rozporządzeniach dotyczących każdej z SSE z osobna (Pach, Grzybczyk, 2003).

W świetle ustawy SSE to wyodrębniona i niezamieszkana część terytorium Rzeczpospolitej Polskiej, na którym podmioty gospodarcze po uzyskaniu zezwolenia mogą prowadzić dzialalność gospodarczą, a po spełnieniu określonych wymogów uzyskują prawo do częściowego lub pelnego zwolnienia z podatku dochodowego. Uprzywilejowanie strefy polega na stworzeniu dla działających $w$ niej podmiotów gospodarczych korzystniejszych warunków prawnych, administracyjnych, fiskalnych, celnych lub finansowych w porównaniu do tych, które obowiązują powszechnie na terenie danego kraju.

Specjalne strefy ekonomiczne funkcjonujące w Polsce od początku budzily w Unii Europejskiej kontrowersje, gdyż ulgi stosowane w SSE traktowane byly jako instrument pomocy publicznej, naruszający równoważną konkurencję. W związku z tym pierwotne, bardzo korzystne zwolnienia i ulgi dla przedsiębiorców zostały istotnie ograniczone już przed akcesją Polski do Unii Europejskiej (Jarczewski, 2007: 92). Przystapienie Polski do UE wymusiło harmonizację zasad udzielania pomocy publicznej w strefach, określenia jej limitów, zasad jej kumulowania oraz możliwości udzielenia pomocy eksportowej (Brudlak, 2003). Obecnie pomoc publiczna udzielana jest zgodnic z zasadami unijnymi. Przedsiębiorcy posiadający zezwolenia na działalność w SSE wydane po 31 grudnia 2000 r. mogą korzystać $\mathrm{z}$ pomocy $\mathrm{w}$ formie zwolnień podatkowych $\mathrm{z}$ tytuhu tworzenia nowych miejsc pracy oraz wysokości kosztów kwalifikowanych inwestycji ${ }^{3}$.

Wedlug stanu na dzień 31 grudnia 2012 r. specjalne strefy ekonomiczne w Polsce obejmowaly tereny zlokalizowane w 143 miastach i 203 gminach. Ich łączna powierzchnia wynosiła 15818 ha, a wartość nakładów inwestycyjnych poniesionych przez firmy w specjalnych strefach ekonomicznych przekroczyła 79.67 mld zl (sejm.gov.pl. 30.01.2013).

Generalnie rzecz biorąc, ze względu na cele można podzielić ogól SSE na:

1. strefy będące narzędziami restrukturyzacji i modernizacji starych okręgów przemysłowych: Walbrzyska SSE, Katowicka SSE. Lódzka SSE. Legnicka SSE. SSE „Starachowice”, SSE EURO-PARK Mielec, Tarnobrzeska SSE;

2. strefy wykorzystujące przygraniczne polożenie do rozwoju regionalnego, zwiększenia przedsiębiorczości poprzez przyciągnięcie inwestorów, np. Kostrzyńsko-Słubicka SSE;

3. strefy będace instrumentami aktywizacji gospodarczej regionu: Suwalska SSE, Słupska SSE, Warmińsko-Mazurska SSE;

4. strefy będące instrumentami eliminacji bezrobocia i tworzenia nowych miejsc pracy: Kamiennogórska SSE, Pomorska SSE i in.;

${ }^{2}$ Por. ustawy z dnia: 16 listopada 2000 r. (Dz.U. z $2000 \mathrm{Nr} 117$, poz. 1228), 2 października 2003r. (Dz.U. z 2003, Nr 188, poz. 1840), 23 czerwca 2006 r. (Dz.U. z 2006, Nr 141, poz. 997) oraz 30 maja 2008 r. (Dz.U. z 2008, Nr 118, poz. 746).

${ }^{3}$ Kwestię pomocy publicznej reguluje ustawa z dnia 30 kwietnia $2004 \mathrm{r}$. o postępowaniu w sprawach dotyczących pomocy publicznej(Dz.T. Nr 123, poz. 1291 i dalsze zmiany Dz.U. z 2007 r. Nr 59, poz. 404). 
5. strefy będące instrumentami wykorzystania i rozwoju zaplecza naukowo-badawczego: Krakowski Park Technologiczny.

Szczególny rodzaj SSE stanowią parki technologiczne, nazywane też parkami nauki lub technoparkami, których powstanie związane jest z umiędzynarodowieniem działalności gospodarczej. wzrostem roli informacji, wiedzy i innowacji we współczesnej gospodarce ${ }^{4}$ :

- bazują na prawnie uregulowanej i wyodrębnionej, samodzielnie zarządzanej nieruchomości, obejmującej konkretny teren i/lub budynki wraz z infrastrukturą techniczną;

- wykorzystują zaawansowane technologie, zatrudniają pracowników o wysokim poziomie wykształcenia i kompetencji, wspólpracują z laboratoriami badawczymi, uczelniami i instytutami naukowymi, lokalną i regionalną administracją publiczną, instytucjami wspierajacymi przedsiębiorczość i transfer technologii;

- stwarzają z posiadanych nieruchomości, świadczonych uslug, doradztwa możliwość korzystania przedsiębiorcom. z nowoczesnej infrastruktury przemyslowej i naukowo-badawczej oraz z ulatwionego dostępu do grantów i dotacji rządowych;

- korzystają ze zwolnień podatkowych po spełnieniu warunków przewidzianych ustawą.

W Polsce funkcjonują parki przemysłowe, technologiczne, inkubatory przedsiębiorczości (ryc. 1) oraz instytucje pośrednie pomiędzy parkiem przemyslowym i technologicznym, określane mianem parku przemysłowo-technologicznego, np. Plocki Park PrzemyslowoTechnologiczny.

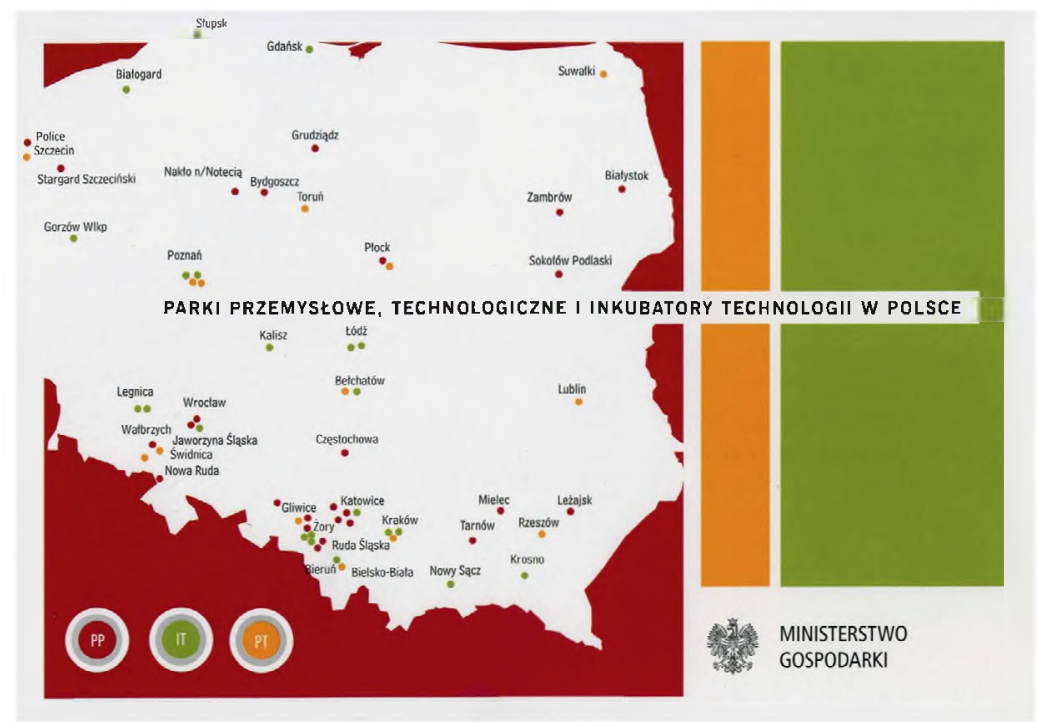

Ryc. 1. Parki przemysłowe, technologiczne i inkubatory technologii w Polsce

Źródło: http://www.mg.gov.pl/Wspieranie+przedsiebiorczosci

4 Jednym z bardziej znanych parków zaawansowanej technologii jest Międzynarodowy Park Działalności Valbonne - Sophia Antipolis, w którym w 2000 r. istniało 25 tys. miejsc pracy; por. Mazur (2004: 33-34). 
Dwadzieścia najdynamiczniej rozwijających się parków zajmuje niemal 1,3 tys. ha, z czego zagospodarowanych jest prawie 550 tys. $\mathrm{m}^{2}$. Stanowi to niewiele powyżej $3 \%$ ich calkowitej powierzchni. Największe są parki technologiczne z Krakowa, Bełchatowa i Plocka oraz podkarpacki Aeropolis. Stanowią one lącznie $88 \%$ całkowitej powierzchni dwudziestu najprężniej dzialających parków ${ }^{5}$.

\section{Krakowska Specjalna Strefa Ekonomiczna - Krakowski Park Technologiczny}

Krakowska Specjalna Strefa Ekonomiczna (KSSE) została powolana na podstawie ustawy z dnia 20 października 1994 r. o specjalnych strefach ekonomicznych, rozporządzeniem Rady Ministrów z dnia 14 października 1997 r. na okres 20 lat (par. 1 ust. 1 ustawy z dnia 14 października 1997 r.; Dz.U. z 1997 r. Nr 135, poz. 912 ze zm.) z możliwością przedłużenia. Posiada status parku technologicznego i jest zarządzana przez spółkę Krakowski Park Technologiczny (KPT). Stanowi unikalne polączenie idei parku technologicznego z SSE, co pozwala jej w sposób zintegrowany oddziaływać na rozwój Malopolski.

KSSE jest jedyną w Polsce strefą ekonomiczną pelniącą równocześnie funkcję parku technologicznego, jak również jedynym w naszym kraju parkiem technologicznym ze statusem SSE. Jego głównym celem jest stworzenie warunków dla przeplywu wiedzy i technologii pomiędzy jednostkami naukowymi a przedsiębiorcami, współpraca z zapleczem naukowo-badawczym, komercjalizacja efektów badań.

W skład Krakowskiej Specjalnej Strefy Ekonomicznej wchodzi 25 podstref, znajdujących się na obszarze 23 gmin: Kraków Śródmieście, Kraków Podgórze, Kraków Nowa Huta, Andrychów, Boguchwała, Bochnia. Bukowno, Chelmek, Chrzanów, Czorsztyn, Dąbrowa Tarnowska, Dobczyce. Gdów, Krosno. Limanowa. Niepolomice. Nowy Sącz, Oświęcim, Skawina, Słomniki, Tarnów. Trzebinia. Wolbrom. Zabierzów, Zator (Krakowski Park Technologiczny, 2013).

Przy tworzeniu KPT szczególnego znaczenia nabraly naukowo-oświatowego charakter miasta Krakowa. baza naukowo-badawcza uczelni. instytutów badawczych obecność już wielu inwestorów zagranicznych, a tym samym możliwość adaptacji. wykorzystania i rozwoju przez przedsiębiorców myśli naukowo-technicznej. Istotnymi celami utworzenia KPT było przełamanie wielu barier rozwojowych w regionie, restrukturyzacja i modernizacja regionu oraz zagospodarowanie istniejącego majątku przemysłowego (Rozporządzenie Ministra Gospodarki z dnia 2 lipca 2009 r.; Dz.U. z 2009 r. Nr 112). Poprzez stworzenie nowych miejsc pracy chodzilo o obniżenie bezrobocia. wzrost konsumpcji i inwestycji. dochodów mieszkańców. wykorzystanie nowoczesnych technologii, a tym samym zwiększenie konkurencyjności wytwarzanych wyrobów, przekladającej się na rozwój Małopolski (Pach, Grzybczyk, 2003). Do strategicznych celów KPT, poza inspirowaniem powstawania innowacyjnych przedsiębiorstw technologicznych oraz usprawnianiem transferu technologii.

${ }^{5}$ http://www.egospodarka.pl/50279.Parki-technologiczne-w-Polsce,2,20,2.html (5.07.2014) 
zalicza się również komercjalizację rezultatów badań naukowych krakowskich wyższych uczelni i instytucji badawczych oraz inicjowanie wspólpracy przemysłu z środowiskiem akademickim. Realizacja tych zadań wiąże się z poszukiwaniem odpowiednich pod względem branży i kapitalu inwestorów, chcących prowadzić dzialalność gospodarczą na terenie specjalnej strefy ekonomicznej oraz w innych rejonach Krakowa i Małopolski.

Tab. I. Główni inwestorzy na terenie SSE Krakowski Park Technologiczny

\begin{tabular}{|l|l|l|}
\hline \multicolumn{1}{|c|}{ Inwestor } & \multicolumn{1}{c|}{ Kraj pochodzenia } & \multicolumn{1}{c|}{ Sektor } \\
\hline ComArch S.A. & Polska & IT \\
\hline RR Donnelley sp. z.o.o. & USA & Poligrafia \\
\hline Motorola Polska Electronics Sp. z o.o. & USA & Elektronika \\
\hline MAN Trucks Sp. z o.o. & Niemcy & Motoryzacja \\
\hline Shell Polska Sp. z o.o. & Wielka Brytania/Holandia & BPO \\
\hline Grupa Onet.pl & Polska/Holandia & IT \\
\hline Ericpol Sp. z o.o. & Polska & IT \\
\hline HCL Poland Sp. z o.o. & Indie/USA & IT \\
\hline $\begin{array}{l}\text { Nidec Motors and Actuators (Poland) } \\
\text { Sp. z o.o. }\end{array}$ & Japonia & Motoryzacja \\
\hline UBS Service Centre (Poland) & Szwajcaria & Bankowość \\
\hline Capita & Wielka Brytania & Księgowość \\
\hline
\end{tabular}

Źródło: Polska Agencja Informacji i Inwestycji Zagranicznych S.A. Krakowskı Park Technologiczny, www.paiz.gov.pl

Wbrew powszechnemu wyobrażeniu ponad $60 \%$ działających w KPT firm to małe i średnie polskie przedsiębiorstwa. korzystające z relatywnie dużej pomocy publicznej.

Przedsięwzięcia inwestycyjne ukierunkowane są na technologie systemów informatycznych i sieci telekomunikacyjnych, elektronikę. w tym optoelektronikę i mikroelektronikę, technologie inżynierii materialowej, technologie ochrony zdrowia i inżynierii medycznej. biotechnologie. inżynierię genetyczną, technologie związane z ochroną środowiska i wykorzystaniem odnawialnych i niekonwencjonalnych źródeł energii. projektowanie i wytwarzanie aparatury pomiarowej i badawczej. Na tle innych funkcjonujących stref w Polsce profil inwestycyjny w KSSE jest szczególny, gdyż przeważają inwestorzy z branży IT i outsourcingowej. inwestujący w nowoczesne laboratoria. uslugi cloud computing. powierzchnie biurowe oraz w dostęp do ushug doradczych i szkoleniowych dla firm z sektora ICT.

W skład SSE w Krakowie (KPT) wchodzą: Park Technologiczny Politechniki Krakowskiej (29,27 ha). Park Technologiczny Uniwersytetu Jagiellońskiego w Pychowicach (39,41 ha), Park Technologiczny Huty im T. Sendzimira w Branicach (34.52 ha) oraz Tarnowski Park Przemysłowy „Plastikowa Dolina” (39.07 ha) w Tarnowie. Na terenie strefy jest bardzo dobrze rozwinięta sieć transportowa, umożliwiająca polączenia z Niemcami. Węgrami, Austrią, Słowacją, Czechami. Rosją i Ukrainą, co zwiększa jej atrakcyjność inwestycyjną (Pastusiak, 2011).

Krakowski Park Technologiczny w ramach swojej działalności oferuje (Po sukces idź do..., 2013): 
1. Kompleksowq obstuge inwestorów, będącą jednym z priorytetów dzialalności KPT dla polskich i zagranicznych inwestorów. Ważną rolę odgrywa tu Centrum Business in Małopolska (CeBiM). Gwarantuje ono inwestorowi informacje niezbędne do prowadzenia działalności gospodarczej, oferty inwestycyjne, doradztwo inwestycyjne, pomoc prawną.

2. Tereny pod inwestycje, głównie greenfield, w podstrefach: Boguchwala, Bochnia, Bukowno, Chełmek, Dobczyce, Gdów, Kraków, Limanowa, Niepolomice, Nowy Sącz, Oświęcim, Stomniki, Tarnów, Wolbrom oraz Zator.

3. Pomoc publiczna przyznawaną wg konkretnych kryteriów, m.in.: ilości nowo utworzonych miejsc pracy, wielkości poniesionych przez przedsiębiorcę nakladów inwestycyjnych w związku z realizacją nowego projektu inwestycyjnego oraz wielkości przedsiębiorstwa zlokalizowanego w strefie (male firmy - najwyższy poziom pomocy publicznej, który w województwie malopolskim wynosi $70 \%$; średnie firmy $-60 \%$, duże $-50 \%$ ). Obliczona na podstawie powyższych kryteriów kwota pomocy publicznej może być odebrana przez przedsiębiorcę w postaci nieplaconego podatku dochodowego do końca funkcjonowania strefy (Ustawa z dnia 30 kwietnia 2004 r. o postępowaniu w sprawach dotyczących pomocy publicznej; Dz.U. Nr 123, poz. 1291).

4. Powierzchnie biurowe do wynajęcia. Szczególne znaczenie pod tym względem ma Kraków Business Park - centrum zlokalizowane w Zabierzowie oferujące powierzchnie biurowe dla firm z sektora nowoczesnych uslug. W pięciu funkcjonujących już biurowcach swoją siedzibę znalazły m.in.: Affiliated Computer Services of Poland Sp. z o.o., SHELL Polska Sp. z o.o., HCL Poland Sp. z o.o., UBS Service Centre (Poland) lm-Sp. z o.o., Luxsoft Poland Sp. z 0.o.

5. Szkolenia z zakresu prowadzenia działalności na terenie SSE oraz z zakresu pozyskiwania funduszy na dzialalność gospodarczą, mające na celu przyciągnięcie inwestorów polskich i zagranicznych.

6. Pośrednictwo w obrocie nieruchomościami pod inwestycje na terenie SSE. Jest to ważna pomoc, gdyż w przypadku terenów i budynków nierzadko występują problemy wlasnościowe.

Inwestycje w KPT dotyczą glównie technologii systemów informatycznych i sieci telekomunikacyjnych, poligrafii, elektroniki. projektowania i wytwarzania aparatury pomiarowej i badawczej. Znaczące inwestycje w branży wydawniczej. polączone z wydawaniem oprogramowania komputerowego (IT), zrealizowaly m.in. ComArch S.A. i RR Donnelley. Firmy świadczące ushugi w tym zakresie zainwestowały ok. $771 \mathrm{mln}$ zl, co stanowi 43,5\% lącznej wartości inwestycji zrealizowanych w tej strefie (Informacja o realizacji..., 2012: 25).

Blisko $230 \mathrm{mln}$ zł zainwestowały w roku 2012 firmy dzialające na terenie KSSE, co przyczynilo się do powstania 391 nowych miejsc pracy. Największe nakłady (50 mln zl) poniosla firma Werner Kenkel Południe - producent opakowań tekturowych, działająca na terenie podstrefy w Bochni, która w planach ma zwiększenie zatrudnienia. Nowe inwestycje rozpoczęly bądź planują takie firmy, jak: Valeo Autosystemy Sp. z o.o., Motorola Solutions Systems Polska Sp. z o.o., Dan Cake Polonia Sp. z o.o.. Can - Pack Sp. z o.o., Integer.pl SA. SGL Karbon Polska SA oraz SN Super Snow. Firmy te przygotowały 10 nowych projektów inwestycyjnych o wartości ponad $390 \mathrm{mln}$ zl i planują zatrudnić ok. 900 osób. 
KPT uczestniczy w wielu długoterminowych projektach, które w dużej mierze finansowane są ze środków Unii Europejskiej. Jednym z glównych projektów bieżących jest „Małopolski Park Technologii Informacyjnych - Ośrodek Innowacyjności Krakowskiego Parku Technologicznego", będący klastrem firm z sektora ICT (sieci wspólpracy tworzonych przez świat nauki. administrację publiczną oraz biznes). Ponadto z inicjatywy Krakowskiego Parku Technologicznego powolane zostały jeszcze dwa klastry: Europejskie Centrum Gier i Krakowska Strefa Dizajnu. Projekty te zrzeszają dziesiątki przedstawicieli malopolskich firm, przedsiębiorstw, instytucji, których misją jest wsparcie rozwoju określonego przemysłu w Malopolsce (Informacja o realizacji... 2012: 25)

Do wyróżniających się podstref KSSE należą (Krakowski Park Technologiczny, 2013):

- podstrefa w Niepolomicach. utworzona w 2005 roku na obszarze 140.866 ha, obecnie obejmująca 207.245 ha. Zainwestowalo tam wiele firm reprezentujących tradycyjny przemysł, takie jak: MAN Trucks Sp. z o.o., Nidec Motors and Actuators (Poland) Sp. z o.o., Woodward Governor Poland Sp. z o.o., Meiller Polska Sp. z o.o., Polskie Zaklady Zbożowe „PZZ” w Krakowie S.A, także Coca Cola HBC Polska, Royal Canin czy Crysler. Głównymi czynnikami przyciągającymi inwestorów jest bardzo dobra marka gminy, wysoki poziom obsługi inwestorów, fakt, iż Niepołomice stanowią poważne zaplecze inwestycyjne dla aglomeracji Krakowa. jak również szereg innych czynników ksztaltujących atrakcyjność inwestycyjną gminy;

- podstrefa Zabierzów (Kraków Business Park), utworzona w czerwcu 2005 r. na obszarze 3,3 ha, zwiększonym później do 7,7 ha. Stanowi ona centrum finansowe Małopolski, badawcze oraz informatyczne, które świadczy usługi firmom z całego świata. W podstrefie funkcjonują takie firmy, jak: Affiliated Computer Service of Poland Sp. z o.o., SHELL Polska Sp. z 0.0., Luxsoft Poland Sp. z o.o., HCL Poland Sp. z o.o., UBS Service Center (Poland) Sp. z o.o.;

- podstrefa krakowskiej specjalnej strefy ekonomicznej w Tarnowie, obejmująca obszar 50,293 ha, przyciąga inwestorów wysokim potencjałem przedsiębiorczości i dobrym klimatem dla biznesu. Spółką zarządzającą jest Tarnowski Klaster Przemyslowy S.A. W Tarnowie inwestują małe i średnie polskie i zagraniczne firmy, a wśród nich: Becker Powloki Przemysłowe Sp. z o.o., DORTECH II s.c., ELMARK Tarnów, KON-INS-BUD Montaż Sp. z 0.o., Zakład Elementów Konstrukcyjnych Sp. z o.o. i inne;

- podstrefa $w$ Zatorze jest jedną z najmłodszych i najprężniej rozwijających się podstref. Zostala utworzona w 2009 r. na obszarze 4,9 ha, który obecnie powiększono do 31,8 ha. W Zatorze projekty realizują takie firmy, jak: ZPHiU Witold Płoszczyca, Cordia Plus, FUPH Lokas, Argo-Hytos Polska, Ekowafel, Pro-eko, PROTECH oraz HAT-TRICK.

\section{Wplyw Krakowskiego Parku Technologicznego}

NA ROZWÓJ WOJEWÓDZTWA MAŁOPOLSKIEGO

Rozwój społeczno-gospodarczy, niezależnie od szczebla, jakiego dotyczy (krajowego, lokalnego), wiąże się z określonym ciągiem ukierunkowanych zmian (ilościowych 
i jakościowych), zlożonych z wielu etapów, determinujących strukturę obiektu pod względem układu wewnętrznego, przestrzennego oraz istniejących powiązań i sprzężeń (Chojnicki. 1999: 265-272). Ma on przede wszystkim wymiar:

- gospodarczy, obejmujący rozwój „bazy ekonomicznej” miast i regionów;

- środowiskowy, wiażący się z poprawą i ochroną środowiska naturalnego;

- infratechniczny, obejmujący rozwój takich dziedzin jak: transport, zaopatrzenie w wodę i cieplo, komputeryzację, internet;

- społeczno-kulturowy, związany z efektami zmian demograficznych, poziomem wykształcenia, efektami naśladownictwa itp.;

- przestrzenny, obejmujący zmiany w zagospodarowaniu określonego terytorium (gminy, województwa) poprzez zagospodarowanie nowych terenów, lokalizację firm, instytucji.

Integracja powyższych wymiarów rozwoju, ksztaltowanie właściwych pomiędzy nimi proporcji, zapewniających trwałą poprawę jakości życia, stanowi istotę zrównoważonego rozwoju

Krakowski Park Technologiczny oddziałuje na wszystkie wymienione aspekty rozwoju województwa małopolskiego.

Jako priorytetowe na terenie SSE uznaje się inwestycje w dziedzinach: technologie systemów informatycznych i sieci telekomunikacyjnych, poligrafia, elektronika, projektowanie i wytwarzanie aparatury pomiarowej, motoryzacja, biotechnologia, dzialalność badawczo-rozwojowa.

Przedsięwzięcia inwestycyjne w SSE oceniane są wedhug:

- zakresu i przedmiotu prowadzonej dzialalności;

- wartości bieżących i planowanych inwestycji;

- zadeklarowanego udziału w modernizacji infrastruktury strefy;

- możliwości wspólpracy z podmiotami działającymi w strefie;

- wplywu na środowisko naturalne, działań na rzecz jego poprawy;

- potencjału kooperacyjnego z krakowskimi uczelniami i jednostkami B+R;

- efektów zagospodarowania przestrzennego.

Kryteria przyznania pomocy publicznej i zezwoleń w KPT maja charakter prorozwojowy. Biorą pod uwagę wielkość zainwestowanych środków finansowych. ilość stworzonych miejsc pracy, wielkość firmy. Ponadto obligują przedsiębiorcę korzystającego z pomocy publicznej z tytułu tworzenia nowych miejsc pracy do ich utrzymania przez okres nie krótszy niż 5 lat. Natomiast przedsiębiorca korzystający z pomocy z tytulu kosztów nowej inwestycji jest zobowiązany do prowadzenia działalności gospodarczej przez okres nie krótszy niż 5 lat, utrzymania własności składników majątku, z którymi byly zwiazane wydatki inwestycyjne przez okres 5 lat od dnia wprowadzenia do ewidencji środków trwałych oraz wartości niematerialnych i prawnych, w rozumieniu przepisów o podatku dochodowym.

Prorozwojowe oddzialywanie mają funkcjonujące w ramach KPT klastry. Stanowią one ,geograficzne skupisko wzajemnie powiązanych firm. wyspecjalizowanych dostawców, jednostek świadczących usługi. firm działających w pokrewnych sektorach i związanych z nimi instytucji (na przykład uniwersytetów, jednostek normalizacyjnych i stowarzyszeń branżowych) w poszczególnych dziedzinach, konkurujących między sobą, ale również 
wspólpracujących" (Kierunki rozwoju... 2013). Proces wyjaśniania przyczyn przestrzennej koncentracji dzialalności gospodarczej zaczął się już od A. Marshalla. który wskazał na rolę tzw. zlokalizowanych pozytywnych efektów zewnętrznych, dotyczących: dyfuzji wiedzy, przewagi kreowanej przez lokalny rynek pracy koncentrujący osoby o odpowiednich umiejętnościach oraz sieci powiązań w ramach dużych rynków regionalnych. Jego zdaniem wysoka koncentracja geograficzna działalności gospodarczej w określonych sektorach nie powoduje spadku atrakcyjności rynku, a wprost przeciwnie: stanowi bodziec zachęcający kolejnych przemyslowców do otwierania fabryk właśnie w takich skupiskach (Skawińska, Zalewski, 2009: 19). Klastry stanowią elastyczną formę współpracy horyzontalnej między 3 grupami podmiotów: przedsiebiorstwami, podmiotami naukowo-badawczymi oraz władzami publicznymi. Tworzą one środowisko ulatwiające intensywne procesy interakcji i kooperacji między poszczególnymi podmiotami narodowych i regionalnych systemów innowacji. Przykladem jest funkcjonujący od 2006 r. Klaster LifeScience Kraków, lączący rozwój innowacyjności w sektorze biotechnologii, farmacji, medycyny, produkcji żywności oraz w pozostalych obszarach life science.

Klaster tworzą różne instytucje:

- firmy z sektora biotechnologii, farmacji, medycyny, żywności i ochrony środowiska $(\mathrm{BioF})$;

- wyższe uczelnie i inne jednostki o profilu edukacyjnym (Edu);

- instytuty badawczo-naukowe (B\&R);

- szpitale i fundacje związane z ochroną zdrowia (Zdrowie);

- firmy konsultingowe i inne jednostki otoczenia biznesu (Biz);

- władze lokalne (Gov).

Współpraca w tym klastrze przyczynia się do komercjalizacji wyników badań naukowych, efektywnego transferu wiedzy do praktyki oraz zwiększenia efektywności wykorzystania zasobów naukowych i gospodarczych Małopolski. Przekłada się nie tylko na przyrost produkcji, ale przede wszystkim na wzrost jakości życia mierzonej wskaźnikami uwzględniającymi różne jego aspekty: ekonomiczne, edukacyjne, zdrowotne, środowiskowe, innowacyjności i konkurencyjności gospodarki itp.

Działalność klastra skupia się przede wszystkim na promowaniu i wspieraniu innowacyjności w obszarze life science. Klaster oferuje w szczególności możliwość nawiązania współpracy, ułatwia dostęp do zasobów wiedzy oraz specjalistycznych zespolów badawczych. Wspiera przedsiębiorczość, a także kooperację pomiędzy przedsiębiorstwami i ośrodkami naukowymi.

\section{Podsumowanie}

Krakowski Park Technologiczny stal się lokomotywą rozwoju gospodarczego Małopolski, oddziałując przede wszystkim na:

- wzrost przedsiębiorczości Małopolski poprzez oferowanie uprzywilejowanych warunków dla działalności firm, kompleksową ich obsługę itp. Dotyczy to zarówno małych i średnich przedsiębiorstw. jak również dużych korporacji z udziałem kapitału zagranicznego; 
- wielkość i strukturę inwestycji. m.in. poprzez system zezwoleń, zakres udzielanej pomocy publicznej, kryteria oceny projektów inwestycyjnych uwzględniające m.in: skalę i przedmiot prowadzonej działalności, wartość inwestycji. udział w modernizacji infrastruktury strefy, możliwość współpracy z krakowskimi uczelniami i jednostkami B+R, efekty zagospodarowania przestrzennego;

- restrukturyzację gospodarki Małopolski w kierunku zwiększenia roli sektora high-tech, rozwoju elektroniki, motoryzacji, biotechnologii, dzialalności badawczo-rozwojowej;

- tworzenie nowych miejsc pracy oraz ich utrzymanie. Przedsiębiorca korzystający z pomocy publicznej zobligowany jest nie tylko do ich tworzenia. ale również utrzymania przez określony czas. W ostatnich dwóch latach (okres recesji gospodarczej w UE) W KPT nie tylko nie ubylo miejsc pracy. ale nastapil ich przyrost;

- podnoszenie jakości zasobów pracy. Ważne w tym względzie są staże, kursy. przekwalifikowanie sily roboczej organizowane przez przedsiębiorców oraz współpraca z jednostkami badawczymi, laboratoriami;

- rozbudowę w szerokim rozumieniu infrastruktury w Małopolsce, zarówno „twardej” (drogi, polączenia krajowe i międzynarodowe), jak również „miękkiej” (usługi bankowe. ubezpieczeniowe, consultingowe itp.).

Potwierdzeniem powyższych kierunków oddziaływania KPT jest fakt, iż tylko w lipcu 2014 roku aż 19 firm odebrało zezwolenia na działalność w KSSE. deklarując inwestycje przekraczające $597 \mathrm{mln}$ zlotych oraz zatrudnienie ponad 1,1 tys. osób (Zezwolenia ..., 2014; 7.07.2014).

Reasumując, należy podkreślić, iż KPT oddziałuje na rozwój nie tylko gospodarczy, ale również społeczny, techniczny, technologiczny i środowiskowy, a w efekcie na jakość życia mieszkańców Malopolski. Przyczynia się ponadto do promocji gmin wchodzących w jego sklad Krakowskiego Parku Technologicznego, a także do podnoszenia ich atrakcyjności inwestycyjnej i jakości zarządzania. Ważne znaczenie ma również w kreowaniu dochodów gmin malopolskich, pochodzących z podatków, w których gminy mają swój udzial: podatku dochodowego od osób fizycznych (PIT), podatku dochodowego od osób prawnych (CIT) oraz podatków typowo gminnych (podatku od nieruchomości), a także różnych opłat. Udzielone inwestorom ulgi i zwolnienia podatkowe z nadwyżką rekompensowaną przez bieżące i przyszle dochody z rosnącej w gminach przedsiębiorczości.

\section{Literatura}

\section{References}

Brdulak J. (2003). Ewolucja uprzywilejowania ekonomicznego SSE w Polsce. W: I. Fierla (red.). Regionalne aspekty rozwoju wybranych rodzajów dzialalności gospodarczej w Polsce, Warszawa: Szkoła Główna Handlowa.

Chojnicki Z. (1999). Podstawy metodologiczne i teoretyczne geografii, Poznań: Bogucki Wydawnictwo Naukowe

Gibuła R. (2006). Wplyw regulacji prawnych Unii Europejskiej na polskie specjalne strefy ekonomiczne. Prace Naukowe AE we Wrockawiu, 1147.

Dziennik Ustaw (2000) Dz. U. z 2000 Nr 117, poz. 122.

Dziennik Ustaw (2006) Dz. U. z 2006 Nr 141, poz. 997. 
Gwosdz K., Jarczewski W., Huculak M., Wiedermann K. (2005). Specjalne strefy ekonomiczne w Polsce. Zalożenia a praktyka. W: Domański B., Gwosdz K.J. (red.). Dziesięć lat doświadczeń pierwszej polskiej specjalnej strefy ekonomicznej. Mielec 1995-2005. Kraków-Mielec: IGiGP UJ w Krakowie, Agencja Rozwoju Przemysłu w Mielcu.

Informacja o realizacji ustawy o specjalnych strefach ekonomicznych. Ministerstwo Gospodarki (2012), sejm.gov.pl (stan: 31.12.2012; dostęp: 30.01.2013).

Jarczewski W. (2007). Specjalne Strefy Ekonomiczne w gminach Samorząd terytorialny, 7-8.

Mazur K. (2004). Specjalne Strefy Ekonomiczne jako nowe obszary przemystowe. Gliwice: Wydawnictwo Politechniki Śląskiej.

Pach J., Grzybczyk G. (2003), Krakowski Park Technologiczny (w założeniach i praktyce). Krakowskie Studia Matopolskie, 7(7).

Pastusiak R. (2011), Specjalne strefy ekonomiczne jako stymulator rozwoju gospodarczego. Lódź.

Rozporządzenie Rady Ministrów z dnia 10 grudnia 2008 r. w sprawie pomocy publicznej udzielanej przedsiębiorcom działającym na podstawie zezwolenia na prowadzenie działalności gospodarczej na terenie specjalnych stref ekonomicznych (2008). Dziennik Ustaw z 2008 r. Nr 232, poz. 1548 , późniejsza zmiana (Dz.U. z 2010 r. Nr 15, poz. 78).

Rozporządzenie Ministra Gospodarki z dnia 2 lipca 2009 r. w sprawie powierzenia Krakowskiemu Parkowi Technologicznemu Sp. z o.o. udzielania zezwoleń na prowadzenie dzialalności gospodarczej na terenie Krakowskiego Parku Technologicznego oraz wykonywania kontroli realizacji warunków zezwolenia (2009). Dziennik Ustaw z 2009 r. nr 112, poz. 927.

Skawińska, E, Zalewski, R. (2009). Klastry biznesowe w rozwoju konkurencyjności i innowacyjności regionów. Warszawa.

Ustawa z dnia 20 października 1994 r. o specjalnych strefach ekonomicznych - tekst jednolity (2007). Dziennik Ustaw Nr 42, poz. 273.

Ustawa z dnia 2 października 2003 r. o zmianie ustawy o specjalnych strefach ekonomicznych i niektórych ustaw (2003). Dziennik Ustaw Nr 188, poz. 1840.

Ustawa z dnia 30 kwietnia 2004 r. o postępowaniu w sprawach dotyczących pomocy publicznej (2004). Dziennik Ustaw Nr 123, poz. 1291.

Ustawa z dnia 30 maja 2008 r. o zmianie ustawy o specjalnych strefach ekonomicznych (2008). Dziennik Ustaw Nr 118, poz. 746.

Źródla internetowe

Kierunki rozwoju klastrów w Polsce, Ministerstwo Gospodarki, Departament Rozwoju Gospodarki (2013). Pozyskano z http://www.mg.gov.plgv2 (13.08.2013),

Krakowski Park Technologiczny (2013). Pozyskano z www.sse.krakow.pl (10.09.2013),

Po sukces idź do Krakowskiego Parku Technologicznego (2013). Pozyskano z www.sse.krakow.pl (16.09.2013).

Parki-technologiczne-w-Polsce,2,20,2.html http://www.egospodarka.p1/50279 (5.07.2014).

Parki technologiczne w Polsce (2010). Nowe zezwolenia w Krakowskiej SSE. Pozyskano z http:// biznes.onet.pl/praca/nowe (7.07.2014).

Janina Pach - doktor habilitowany nauk ekonomicznych, profesor nadzwyczajny, Kierownik Katedry Ekonomii i Polityki Gospodarczej w UP w Krakowie. Autorka licznych artykulów naukowych z dziedziny ekonomii, międzynarodowych stosunków gospodarczych, finansów publicznych i polityki gospodarczej, autorka i współautorka publikacji książkowych. Dorobek naukowy ogniskuje się przede wszystkim na:

- międzynarodowych przepływów myśli naukowo-technicznej,

- międzynarodowych przeplywów kapitałowych, w tym bezpośrednich inwestycji zagranicznych i kredytów zagranicznych,

- różnych aspektów funkcjonowania malych i średnich przedsiębiorstw,

- finansów państwa, ze szczególnym uwzględnieniem polityki budżetowej. 
Janina Pach - Associate Professor of Economic Sciences, Head of Department of Economics and Economic Policy of Pedagogical University of Cracow. The author of numerous scientific articles in the field of economics, international economic relations, public finance and economic policy, chapters in books, and books. Scientific achievements focus mainly on:

- international flows of scientific and technical solution,

- international capital flows, including foreign direct investments and foreign loans,

- various aspects of the functioning of small and medium enterprises,

- public finance, with special emphasis on fiscal policy.

\section{Adres/adress:}

Uniwersytet Pedagogiczny im. KEN w Krakowie

Instytut Politologii

Katedra Ekonomii i Polityki Gospodarczej

ul. Podchorążych 2, 30-084 Kraków, Polska

janina.pach@poczta.onet.pl 